\title{
Components of standard metabolic rate variability in three species of gammarids
}

\author{
Milad Shokri, Mario Ciotti, Fabio Vignes, Vojsava Gjoni, and Alberto Basset \\ Department of Biological and Environmental Sciences and Technologies, University of Salento, \\ 73100 Lecce, Italy \\ Correspondence: Milad Shokri (milad.shokri@unisalento.it)
}

Received: 2 May 2018 - Revised: 25 November 2018 - Accepted: 4 December 2018 - Published: 8 January 2019

\begin{abstract}
Standard metabolic rate is a major functional trait with large inter-individual variability in many groups of aquatic species. Here we present results of an experimental study to address variation in standard metabolic rates, over different scales of organisation and environments, within a specific group of aquatic macroinvertebrates (i.e. gammarid amphipods) that represent the primary consumers in detritus food webs. The study was carried out using flow-through microrespirometric techniques on male specimens of three gammarid species from freshwater, transitional water and marine ecosystems. We examined individual metabolic rate variations at three scales: (1) at the individual level, during an $8 \mathrm{~h}$ period of daylight; (2) at the within-population level, along body-size and body-condition gradients; (3) at the interspecific level, across species occurring in the field in the three different categories of aquatic ecosystems, from freshwater to marine.

We show that standard metabolic rates vary significantly at all three scales examined, with the highest variation observed at the within-population level. Variation in individual standard metabolic rates during the daylight hours was generally low (coefficient of variation, $\mathrm{CV}<10 \%$ ) and unrelated to time. The average within-population $\mathrm{CV}$ ranged between $30.0 \%$ and $35.0 \%$, with body size representing a significant source of overall inter-individual variation in the three species and individual body condition exerting only a marginal influence. In all species, the allometric equations were not as steep as would be expected from the $3 / 4$ power law, with significant variation in mass-specific metabolic rates among populations. The population from the transitional water ecosystem had the highest mass-specific metabolic rates and the lowest within-population variation.

In the gammarid species studied here, body-size-independent variations in standard individual metabolic rates were higher than those explained by allometric body size scaling, and the costs of adaptation to short-term periodic variations in water salinity in the studied ecosystems also seemed to represent a major source of variation.
\end{abstract}

\section{Introduction}

Transitional waters are ecotone ecosystems occurring at the interface between terrestrial, marine and freshwater ecosystems (Basset et al., 2013); they are highly productive and valuable aquatic ecosystems (Costanza et al., 2014; Madricardo et al., 2017), shaped by strong contrasting forces (Basset et al., 2013) and subject to multiple disturbance pressures (Elliott and Quintino, 2007).

The spatial and temporal variability of water salinity (Akin et al., 2005; Basset et al., 2013), the high nutrient supply and the strong gradients of both nutrient concentrations (PérezRuzafa et al., 2005; Basset et al., 2013) and dissolved oxygen
(Hull et al., 2008; Cozzoli et al., 2013; Shokri et al., 2014) are the main "natural" sources of disturbance. Potential coloniser species, being of freshwater and marine origin (Barnes, 1989; Ciotti et al., 2015), need to cope with these sources of disturbance and particularly with water salinity variability and the related osmoregulation costs, which drive species' standard metabolic rates.

Individual standard metabolic rate in relation to body size has been studied in many aquatic species, especially pelagic and non-pelagic invertebrates (Glazier, 2005) including crustaceans (Ivleva, 1980; Childress et al., 1990), insects (Gutiérrez and Menéndez, 1997) and molluscs (Xiao et al., 2014), 
as well as fish (Killen et al., 2010; Brucet et al., 2012). Among invertebrate species, the metabolic rates of crustacea such as Cladocera (Hart and Bycheck, 2011) and Amphipoda (mainly gammarids; Dorgelo, 1973) have received particular attention due to the relevance of these groups of species to the ecological status of aquatic ecosystems (Altermatt et al., 2014). Regarding gammarids, on which this study is focused, metabolic rates have primarily been addressed in a small number of species that have been proposed for use in bio-monitoring (e.g. the freshwater Gammarus pulex (Toman and Dall, 1998; Foucreau et al., 2014) and Gammarus minus (Lowenstein, 1935; Dorgelo, 1973); the transitional water Gammarus insensibilis (Gates, 2006); and the marine Gammarus oceanicus (Halcrow and Boyd, 1967)) and have tended to explore average metabolic rates rather than their variations, despite the relevance of gammarids to all types of aquatic ecosystems and the importance of individual metabolic rates as a key individual trait (Speakman et al., 2004). Gammarids include widely distributed amphipod species inhabiting freshwater, brackish and marine ecosystems (Tedengren et al., 1988) that are generally characterised by their higher energy requirements than other closely related Malacostraca (Hamburger and Dall, 1990).

Allometric variations of metabolic rate with individual body mass have been described (West et al., 1997, 2002; Brown and West 2000; Brown et al., 2004), and the consistency and deviation of the slope of the allometric equations with respect to the expected value of $3 / 4$ has been discussed with reference to metabolic level (Glazier, 2005, 2009; Duncan et al., 2007; Sieg et al., 2009; White et al., 2009) and, particularly in ectotherms, metabolic state (White et al., 2004). In this regard, researchers have also considered ontogenic shifts in individual body shape (Hirst et al., 2014), the metabolic intensity of growth, reproduction and locomotion (Glazier, 2005), and body-size-dependent biological regulation (Glazier et al., 2015). However, the degree of variability of intra-population standard metabolic rates and the meaning and sources of such variability have received less attention, even when the implications of the allometric scaling of metabolic rates in the context of global warming are addressed (Forster et al., 2012). There is now growing interest in the ecological basis of metabolic rate variability at the individual level, which would allow a more accurate evaluation of the integrated responses of plant and animal communities to global warming (Bruno et al., 2015), ocean acidification (Lannig et al., 2010) and chemical contamination (Johnston et al., 2015). Moreover, there is increasing evidence that very small-scale, intra-individual variation may have manifold ecological consequences for population and community ecology (Herrera, 2017). In most animals, ecologically significant sub-individual variation is mostly sequential in nature, as it generally arises from ontogenetic and/or seasonal changes in individual traits (e.g. behaviour, colouration, digestive organ size) (Piersma and Lindström, 1997; Delhey and Kempenaers, 2006; Stamps et al., 2012; Herrera, 2017).
Moreover, intra-individual variation has been observed to increase species' niche width (Sides et al., 2014), enhancing community-wide functional diversity (Siefert et al., 2015).

Here, we address individual-level variability in the metabolic rates of three species of gammarid amphipods: Echinogammarus olivii (H. Milne Edwards, 1830), Gammarus insensibilis (Stock, 1966) and Gammarus aequicauda (Martynov, 1931). The aim of this paper is to address the variability of individual metabolic rates at three different levels: (1) at the individual level, during periods of daylight; (2) within populations, across and within individual body size classes; and (3) among species occurring in the field in the three different categories of aquatic ecosystems, from freshwater to marine.

Within-population variation in standard metabolic rates is expected to be higher than both intra-individual and interspecies variation due to the well-known allometric scaling of metabolism with size (Kleiber, 1932; West et al., 1997; Glazier, 2005). However, earlier studies at the population level in aquatic crustaceans (Vignes et al., 2012) have also shown high intra-population variation that is independent of body size, and the relevance of this to both intra-individual and the inter-species variation is also addressed in this study.

\section{Materials and methods}

\subsection{Study area and gammarid collection}

From the taxonomic point of view, the three species selected for this study, i.e. Echinogammarus olivii (Milne Edwards, 1830), Gammarus insensibilis (Stock, 1966) and Gammarus aequicauda (Martynov, 1931), belong to the Gammaroidea superfamily, while in functional terms they are shredders and scrapers. We studied one population per species, which were sampled from coastal marine, transitional water and freshwater ecosystems in the Salentine Peninsula (Fig. 1) in spring 2016 (April until early May).

Echinogammarus olivii (Milne Edwards, 1830) is considered a marine species (Costello, 2001) inhabiting shallow coastal and transitional ecosystems in the Mediterranean Sea and Black Sea (Gönlügür-Demirci, 2006; Varigin, 2015). The maximum body length in males is $13 \mathrm{~mm}$ and females are slightly smaller (Pinkster, 1993). For this study we sampled an E. olivii population colonising - at relatively high densities - coastal marine ecosystems in the area of Sant'Isidoro located on the west coast of the Salentine Peninsula and lying within the Porto Cesareo Marine Protected Area.

Gammarus insensibilis (Stock, 1966) is an AtlanticMediterranean species (Costello, 2001) occurring in both marine and brackish ecosystem types (Gilliland and Sanderson, 2000; Prato and Biandolino, 2005); the maximum body length in males is $19 \mathrm{~mm}$ and females are slightly smaller (WoRMS, http://www.marinespecies.org/, last access: 1 April 2018). This species was sampled in the Acquatina lagoon which is an artificially embanked, small non- 

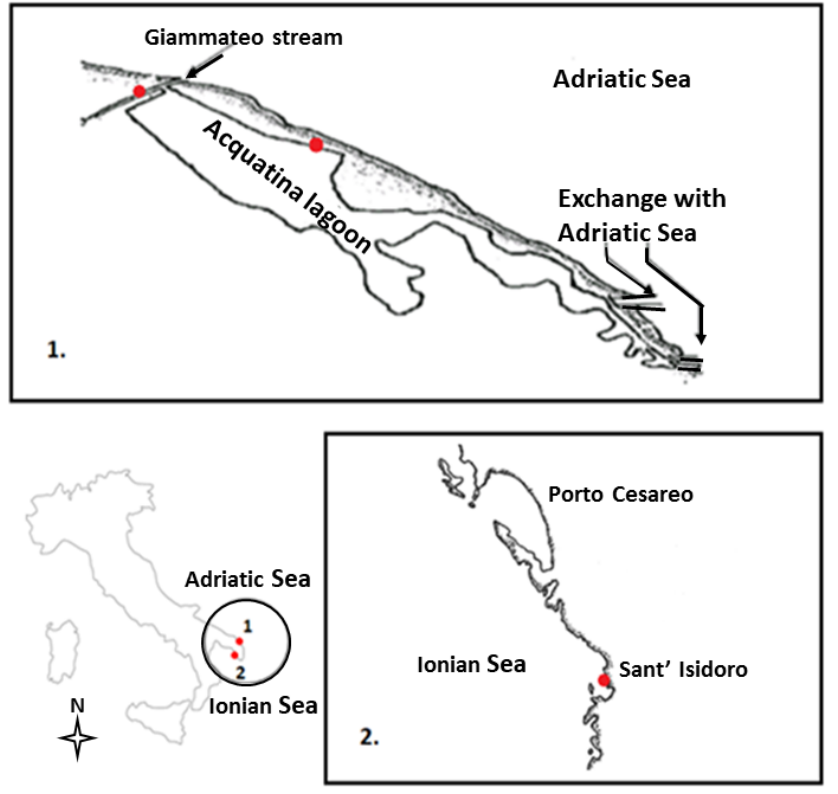

Figure 1. Map of the study area, Salentine Peninsula, Italy.

tidal lagoon located on the Adriatic side of the Salentine Peninsula. The lagoon is relatively shallow and linked to the sea and thus to the neighbouring coastal marine ecosystems by two modified channels. To the north is the Giammatteo channel, almost always closed by accumulations of sand and Posidonia oceanica detritus, and to the south is the main channel. Large meadows of Cymodocea nodosa and Ruppia sp. occur on the south side of the lagoon from spring to autumn (Maci and Basset, 2010). Previous studies of nutrient concentrations and primary producer biomass allow Acquatina to be classified as an oligotrophic basin (Fiocca et al., 1998).

The main freshwater input in Acquatina is a ramification of the Giammatteo channel, fed by precipitation and groundwater (Verschut et al., 2015; Boggero et al., 2017) and characterised by a benthic habitat consisting of rocky boulders and dense accumulations of leaf detritus. It was in this channel that we sampled Gammarus aequicauda (Martynov, 1931), which is one of the most abundant and widely distributed gammarids in the coastal ecosystems of the Mediterranean Sea and Black Sea (Ruffo, 1982). The maximum length is $25 \mathrm{~mm}$ in males and $20 \mathrm{~mm}$ in females (Kevrekidis and Koukouras, 1988).

Specimens were sampled by hand net $(2 \mathrm{~mm}$ mesh) and trophic traps, which consisted of plastic mesh bags of reed leaves (Phragmites australis (Cav.) Trin. ex Steud.) that had previously been conditioned for 14 days (Petersen and Cummins, 1974) using three recirculating experimental channels filled with original water from the field collection sites. The conditioned reed leaves were then left for 1 week at their respective field sites before specimen collection. At least 500 individuals per species per site were collected and attributed to a single population per species since the area sampled was relatively small, corresponding to no more than $100 \mathrm{~m}$ of coastline per site.

\subsection{Laboratory procedures}

Specimens of the three gammarid populations were transferred to the lab at the Experimental Research Centre for Biodiversity and Ecosystems (BIOforIU) of Salento University in thermal-insulated containers filled with water from the sampling sites and aerated during transport. In the lab, specimens were then acclimated for at least 1 week and reared using the BIOforIU integrated microcosm system, which consists of blocks of $32 \mathrm{~L}$ aquaria fed with three lines of artificial water, i.e. fresh, brackish and marine, in order to set the same water salinity as the three gammarid species were experiencing at the field sampling sites. Decaying reed leaves were supplied as food in the aquaria and renewed at weekly or fortnightly intervals depending on consumption. The microcosms have remote controlled temperature and conductivity, and dissolved oxygen can be manipulated when required (http://bioforiu.unisalento.it/, last access: 1 April 2018). Six microcosms per species were used for acclimating specimens to laboratory conditions. A photoperiod of $12 \mathrm{~h}: 12 \mathrm{~h}$ lightdarkness with a constant temperature of $18 \pm 0.3^{\circ} \mathrm{C}$ was applied to all microcosms, and water salinity was set to the values required by the different species, using artificial fresh water (Naylor et al., 1989) as a source of fresh water (0.3 PSU) and artificial salt water $\left(35 \mathrm{~g} \mathrm{~L}^{-1}\right.$ of Askoll marine salt) as a source of marine water. Brackish water (21 PSU) was obtained by mixing fresh water and marine water $(60 \%-40 \%)$. The experimental temperature $\left(18.0^{\circ} \mathrm{C}\right)$ was close to that of the waters of the various field sites at the time of specimen collection (Table 1). The main water parameters for the acclimation period in the aquaria and for metabolic rate assessment are shown in Table 2 for each species.

Before the start of the laboratory experiments, specimens of each species were sorted by sex under a Nikon stereomicroscope (SMZ1270). Only males were selected for laboratory experiments since oocyte production in females has high costs (Glazier, 1991, 2011; Taylor and Leelapiyanart, 2001; Becker, 2016), is brief and is not predictable from an individual's external morphology. Given the high uncertainty in recognising the sex of small individuals, only specimens with a body length of more than $4 \mathrm{~mm}$ were used.

\subsection{Standard metabolic rate}

All the experiments were carried out in a thermostatic room at $18 \pm 0.3^{\circ} \mathrm{C}$. A sample of 60 males per population, covering the whole range of male body size in the population of origin, was used to assess individual standard metabolic rate. However, since some individuals moulted and some died either during the assessment or the following day, the final number of individual standard metabolic rates collected per popula- 
Table 1. Sampling stations, geographical coordinates and mean annual physico-chemical parameters.

\begin{tabular}{lcrrrl}
\hline $\mathrm{pH}$ & $\begin{array}{r}\text { Temperature } \\
\left({ }^{\circ} \mathrm{C}\right)\end{array}$ & $\begin{array}{r}\text { Salinity } \\
(\mathrm{PSU})\end{array}$ & Longitude & Latitude & Study areas \\
\hline $7.52 \pm 0.02$ & $18.22 \pm 0.28$ & $1.72 \pm 0.02$ & 18.232433 & 40.448632 & Giammatteo \\
$8.39 \pm 0.02$ & $20.54 \pm 0.96$ & $22.90 \pm 1.48$ & 18.237752 & 40.445362 & Acquatina \\
$8.22 \pm 0.01$ & $19.16 \pm 0.59$ & $38.30 \pm 0.05$ & 17.926321 & 40.218900 & Sant'Isidoro \\
\hline
\end{tabular}

Table 2. Artificial water parameters used for acclimation and experimental assessment.

\begin{tabular}{lcrl}
\hline $\mathrm{pH}$ & $\begin{array}{r}\text { Temperature } \\
\left({ }^{\circ} \mathrm{C}\right)\end{array}$ & $\begin{array}{r}\text { Salinity } \\
(\mathrm{PSU})\end{array}$ & $\begin{array}{l}\text { Artificial } \\
\text { water lines }\end{array}$ \\
\hline $7.82 \pm 0.5$ & $18 \pm 0.3$ & $0.3 \pm 0.2$ & Freshwater \\
$7.43 \pm 0.6$ & $18 \pm 0.3$ & $21 \pm 1.1$ & Brackish \\
$7.62 \pm 0.5$ & $18 \pm 0.3$ & $35 \pm 0.4$ & Marine \\
\hline
\end{tabular}

tion was slight lower than 60 and differed among populations (E. olivii $-n=44$, G. insensibilis $-n=56$; G. aequicauda $-n=56)$.

Before the assessment, individuals were kept unfed for $24 \mathrm{~h}$ in plastic beakers $(200 \mathrm{~mL})$ in the thermostatic room, after which they were transferred to the metabolic measurement system, which contains a glass water tank filled with the same water as the acclimation aquaria, magnetically stirred (using a AREC.X digital ceramic heating magnetic stirrer) and aerated with compressed air. A peristaltic pump (Watson-Marlow 205U) provided constant water flux. Water was pumped into 12 metabolic chambers $(6 \mathrm{~mL}$ volume), each containing a single individual. Upon exiting the chambers, the water was pumped via silicone tubes to a microelectrode where the oxygen concentration was measured by oxymeter, which transformed the electrical signals into oxygen partial pressure values, which were analysed using Strathkelvin 929 data analysis software. To assess the standard metabolism of individual gammarids, we set the flow rate to approximately $6 \mathrm{~mL} \mathrm{~h}^{-1}$ in order to ensure a $\Delta$ Torr in the experimental chambers of between 4 and 40 Torr, with a residual oxygen saturation of $75 \%-80 \%$. On the basis of the selected flow rate, the water turnover time in the experimental chambers was set at $1 \mathrm{~h}$ and, following Lampert (1984), a $3 \mathrm{~h}$ equilibration time was fixed as the time required to reach a steady concentration of dissolved oxygen. In any case, the flow rate was deterministically assessed each day on each line by weighing the water flowing out through the syringe in a defined time in order to be able to detect any stochastic variations in the flow rate in specific chambers at specific times, avoiding biases in the dataset. The coefficient of variation of the chambers' control readings was lower than $2 \%$. The standard metabolism of each individual was assessed three times in an $8 \mathrm{~h}$ period, the first assessment at the end of the equilibration time and the other two at $2.5 \mathrm{~h}$ intervals.
The three repeated measurements were used only to evaluate intra-individual variation and to determine whether the small experimental chambers were causing stress effects on individual standard metabolism. Every day, two blank measurements were performed, at the beginning and at the end of the measurement in the experimental chambers and all components of the system were cleaned.

The oxygen consumed by each individual $\left(V_{\mathrm{O}_{2}}\right)$ was estimated by calculating the difference between the dissolved oxygen concentration flowing into each experimental chamber and that of the water flowing out of the same experimental chamber, in accordance with the following formula:

$V_{\mathrm{O}_{2}}=($ ppin - ppout $) \operatorname{sc}_{\mathrm{O}_{2}} \mathrm{FR}$,

where ppin is the dissolved oxygen partial pressure in torr of the inflow water (100\% saturation), PPout is that of the outflow water, FR is the water flow rate $\left(\mu \mathrm{molh}{ }^{-1}\right)$ and $\mathrm{sc}_{\mathrm{O}_{2}}$ is the solubility coefficient of dissolved oxygen in water ( $\mu \mathrm{molL} \mathrm{L}^{-1}$ Torr $^{-1}$ ) (Cai et al., 1999). The turnover time $(J)$ needed to reach a steady state depends on the system's characteristic flushing time:

$J(h)=\frac{\omega}{U}$

where $W$ is the chamber volume $(\mathrm{mL})$ and $U$ is the water flow rate $\left(\mathrm{mL} \mathrm{h}^{-1}\right)$ (Lampert, 1984). Metabolic measurements were performed in three replicates for each individual.

\subsection{Specimen body size}

After metabolic measurement, we measured the body length and dry weight of each individual.

For measurement of body length (BL), individuals were anaesthetised in carbon-dioxide-saturated water and measured from the base of the antennae to the beginning of the first urosome (Basset and Glazier, 1995) by an image analysis system (Leica QWIN 3) using a stereomicroscope (Leica MZ12) to the nearest $0.01 \mathrm{~mm}$.

For measurement of body dry weight (DW), the animals were dried individually in an oven at $60^{\circ} \mathrm{C}$ for $72 \mathrm{~h}$ and weighed on a Sartorius MC5 micro balance to the nearest $\pm 0.001 \mathrm{mg}$.

Weight $\times$ length relationships were quantified by fitting the power function: $\mathrm{DW}=a L^{b}$, where $\mathrm{DW}$ is body dry weight (mg) and $L$ is standard body length (in $\mathrm{mm}$ ). 
We also estimated the body condition index (BCI), which reflects an animal's energetic state and is generally considered to be an indicator of its health, quality, and vigour (Rowe and Houle, 1996; Schulte-Hostedde et al., 2005; Peig and Green, 2009; Cox et al., 2014). Here, BCI is expressed as the residuals in log scale of each individual body weight from what was expected from the weight $\times$ length relationship (Jakob et al., 1996), in accordance with the following formula:

$\mathrm{BCI}=\log \left(\mathrm{DW}_{\mathrm{i}}\right)-\log \operatorname{Expected}(\mathrm{DW})$,

where Expected $(\mathrm{DW})=\log (a)-(b) \log \left(L_{\mathrm{i}}\right)$ is the predicted DW for an average individual of length $L_{\mathrm{i}}$, obtained from all individuals in a given population.

\section{Data analysis}

The mass-specific standard metabolic rate (mass-specific SMR) at the individual level, defined as the resting energy expenditure per unit body mass per day, was computed here with individual body mass expressed as individual dry weight (Wilhelm et al., 2006; Glazier et al., 2011; Lagos et al., 2017), in accordance with the following formula:

mass-specific standard metabolic rate $=\frac{M_{\mathrm{O}_{2}}}{\mathrm{DW}}$,

where $M_{\mathrm{O}_{2}}$ is the individual standard metabolic rate and DW is the individual dry weight. The coefficient of variation was calculated from daily replicate SMR measurements for each species, and compared among species with one-way ANOVA.

We used parametric statistics (one-way ANOVA) to compare the mean values for weight, length and standard metabolic rates among the three species, considering that these tests were statistically independent and, therefore, individual $p$ values were interpreted with caution.

Standard metabolic rates were compared among populations using ANCOVA with log-transformed data in order to linearise the relationship with body dry weight (covariable) and to meet model assumptions of the normality of residuals and homogeneity of variance. The assumption of slope homogeneity (interaction between populations and slope) was tested before conducting comparisons among populations.

Standard OLS regression analyses were used to measure the linear dependency of mass-specific standard individual metabolic rates on individual body condition (BCI) and body dry weight (DW), respectively.

\section{Results}

\subsection{Individual body size}

The body length of male individuals ranged from 4.4 to $13.0 \mathrm{~mm}$ and their body weight from 0.59 to $8.21 \mathrm{mg}$. The average individual body length differed significantly among species (one-way ANOVA: $F_{2,133}=4.619, P<0.05$ ), with E. olivii individuals smaller than those of $G$. aequicauda (post hoc Student's $t$ test, $P<0.05$ ), while individual body weight did not differ among species $\left(F_{2,133}=1.596, P>\right.$ 0.05 ).

For all three species, significant weight $\times$ length relationships were observed. They explained $55.4 \%$ and $91.0 \%$ of body weight variation for E. olivii and G. insensibilis respectively (Fig. 2). Overall, the slopes of the weight-length relationships differed significantly among species (ANCOVA: $F_{2,130}=7.23, P<0.05$ ). Regarding species pairs, the slope of the $G$. insensibilis weight $\times$ length relationship was higher than those of $G$. aequicauda and E. olivii (a post-hoc ANOVA, Tukey's multiple comparison: $F_{2,130}=7.23, P<$ 0.0001). The slopes of the G. aequicauda and E. olivii weight $\times$ length relationships did not differ, allowing a comparison between the intercepts, which were higher in the latter than the former (ANCOVA: $F_{1,78}=5.35, P<0.05$ ). The unexplained variance of the weight $\times$ length relationships was assumed to be due to differences in body condition between individuals. The intra-population variation in body condition was higher in E. olivii than in G. insensibilis (twotailed $F$ test $=1.94$; d.f. $=90 ; P<0.05$ ), while there were no differences between the other species pairs.

\subsection{Individual standard metabolic rates}

The standard metabolic rate of the individuals of the three species ranged between 0.42 and $3.71 \mathrm{~J} \mathrm{~d}^{-1}$, considering differences in standard metabolic rate over time for each individual, among individuals of the same population and among the three species.

The differences in the standard metabolic rate of each individual during the $8 \mathrm{~h}$ period are expressed as the coefficient of variation $(\mathrm{CV} \%)$. The intra-individual $\mathrm{CV} \%$ was generally low and independent of the time spent by individuals in the experimental chambers. In only $4 \%$ of the tested individuals did their average standard metabolic rates have coefficients of variation higher than $20 \%$, and the average $\mathrm{CV} \%$ at the population level lay within in a very restricted range: from $8.94 \% \pm 5.91 \%$ (Gammarus aequicauda) to $9.68 \% \pm 5.41 \%$ (Gammarus insensibilis) (Fig. 3). Moreover, standard metabolic rates at the individual level showed no pattern of variation among repeated measurements of the same individual (paired Student's $t$ test, not significant for all comparisons). Hereafter, only the values of individual average standard metabolic rate were used for analyses.

Overall, while individual body mass did not vary significantly among species, average standard metabolic rates were higher in Gammarus aequicauda $\left(1.55 \pm 0.49 \mathrm{~J} \mathrm{~d}^{-1}\right)$ than Gammarus insensibilis $\left(1.46 \pm 0.50 \mathrm{~J} \mathrm{~d}^{-1}\right)$ and Echinogammarus olivii $\left(1.11 \pm 0.36 \mathrm{~J} \mathrm{~d}^{-1}\right.$ ), (ANOVA: $F_{2,150}=12.711$, $P<0.05)$ (Fig. 4). 

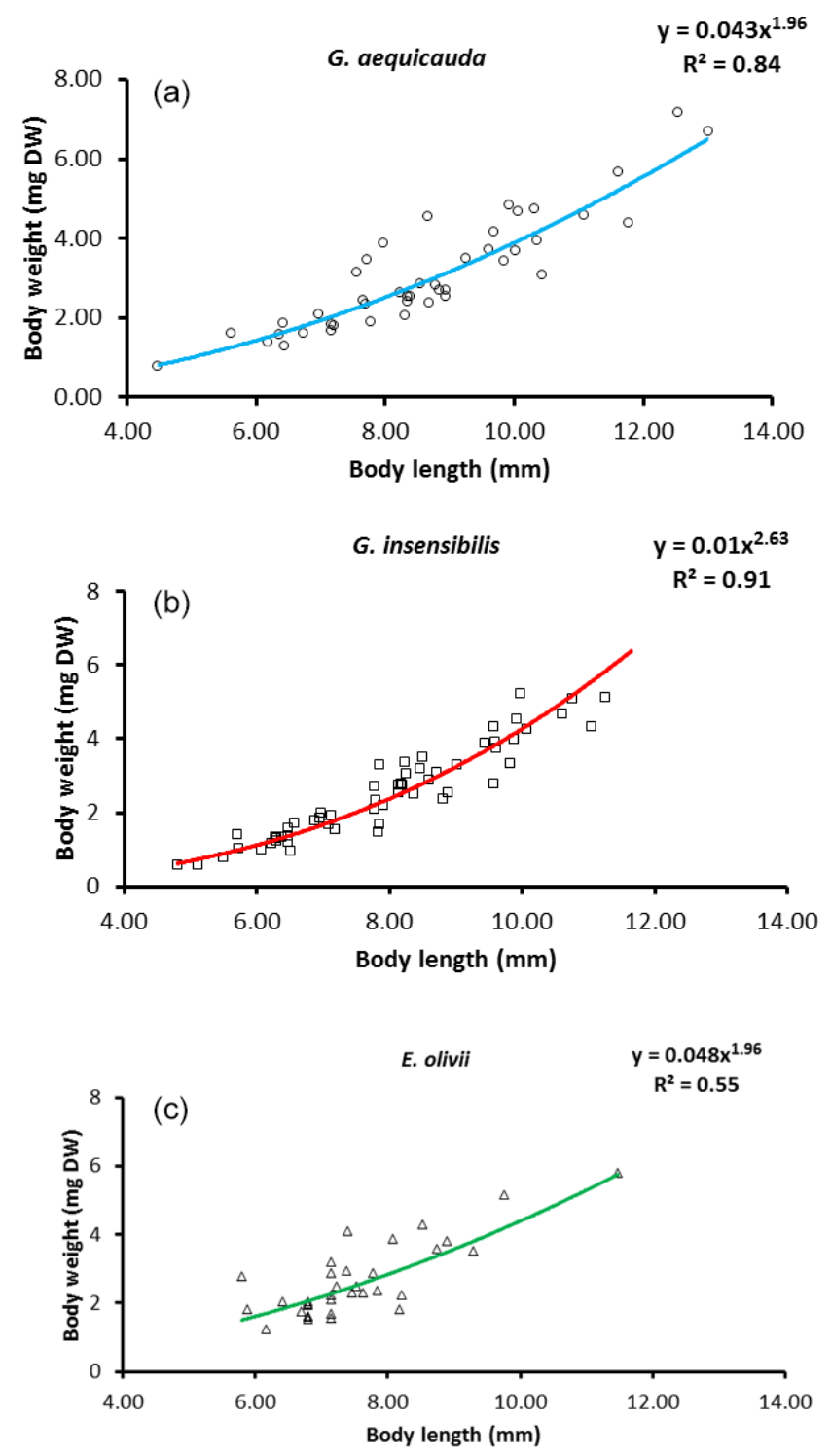

Figure 2. Weight $\times$ length allometric relationships in species sampled in freshwater (a), brackish (b) and marine (c) ecosystems.

The standard individual metabolic rates of all species showed significant allometric variation, and the linear fits were significant (ANOVA ${ }^{a}$ : G. aequicauda $-F_{2,54}=$ 11.27, $P<0.05$; $G$. insensibilis $-F_{2,54}=38.67, P<0.05$; E. olivii $-F_{2,42}=5.86, P<0.05$; Fig. 5), with slopes ranging from $0.36 \pm 0.050$ to $0.32 \pm 0.095$ and explained variation ranging from $12.2 \%$ to $41.7 \%$. All the slopes were significantly lower than $b=0.75$ (ANCOVA: Gammarus aequicauda $-F_{1,42}=5.87, P<0.01$; Gammarus insensibilis $-F_{1,54}=36.67, P<0.001 ;$ Echinogammarus olivii - $\left.F_{1,54}=11.27, P<0.001\right)$. The differences among the slopes were not significant (ANCOVA: $F_{2,150}=0.466, P>$ 0.05 ), while the intercepts differed significantly (ANCOVA: $F_{2,150}=14.86, P<0.0001$ ), with higher intercepts in Gam-

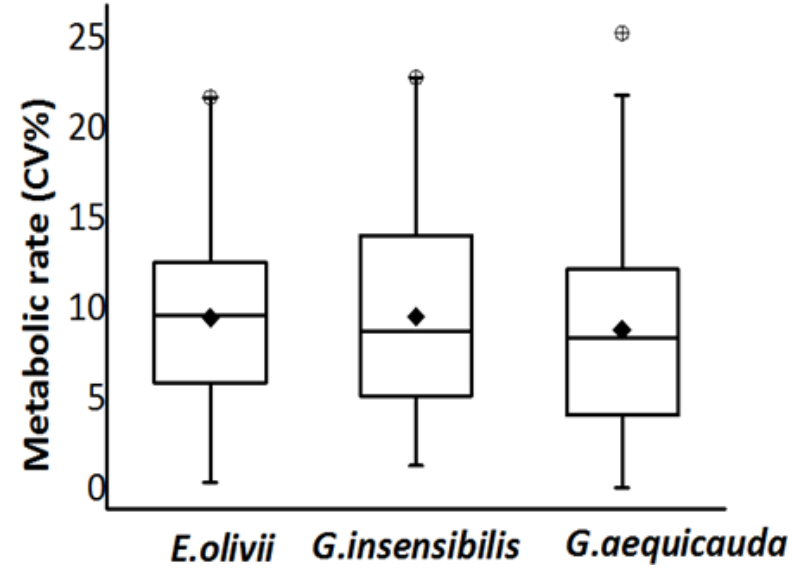

Figure 3. Coefficient of variation of the standard metabolic rate of the three species at the individual level during the experimental period (confidence interval: $95 \%$ ).

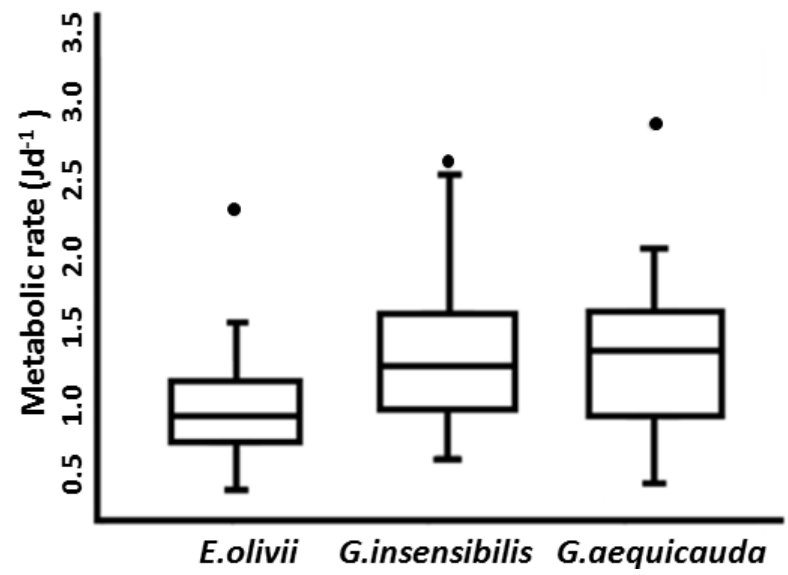

Figure 4. Average standard metabolic rates of the three species. For each species the box represents the interquartile (confidence interval: $95 \%)$

marus aequicauda ( $y$ intercept; $0.062 \pm 0.11$, d.f. $=54$ ) than Gammarus insensibilis ( $y$ intercept; $0.03 \pm 0.06$, d.f. $=54$ ) and Echinogammarus olivii ( $y$ intercept; $-0.246 \pm 0.133$, d.f. $=42$ ). The mass-specific variation of standard individual metabolic rates was not related to individual body size, while it was marginally related to individual body condition, since body-size-independent standard metabolic rates, as residuals from the allometric scaling equations, decreased with body condition in Gammarus aequicauda (Fig. 6; $y=-1.085 x+$ 0.631 ; d.f. $=42 ; P<0.05)$, although the explained variance was only $9.4 \%$.

\section{Discussion}

Since the first few decades of the 20th century (Kleiber, 1932), it has been observed that common body-sizedependent scaling patterns of basal and standard 


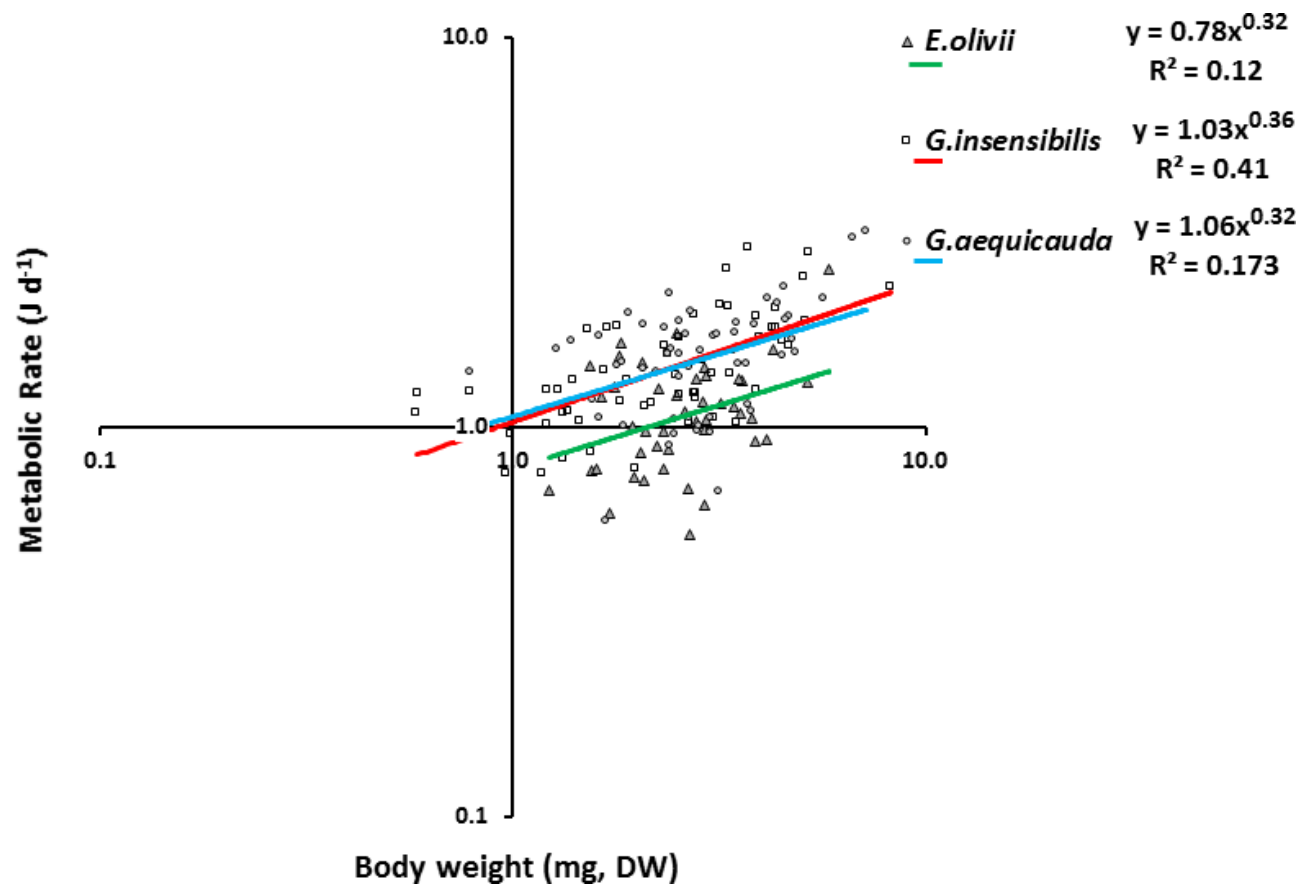

Figure 5. The relationship of body dry weight to standard metabolic rate in the three species.

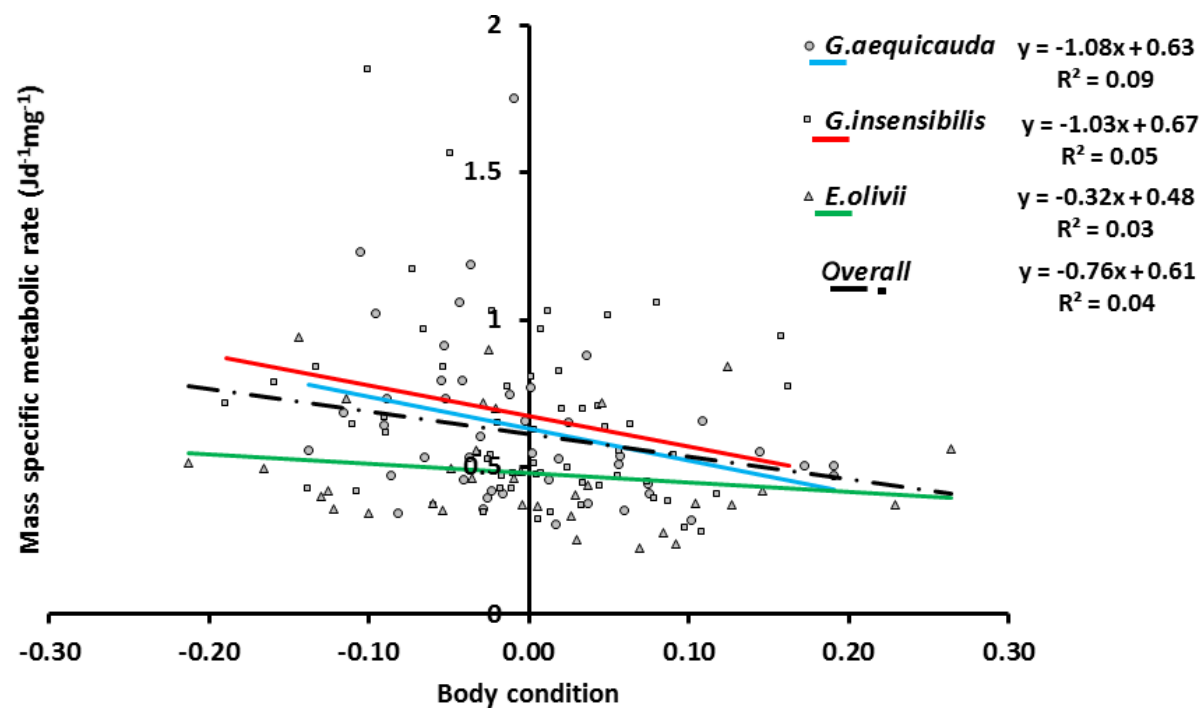

Figure 6. The relationship of body condition index to mass-specific standard metabolic rate in the three species.

metabolism, from unicellular to multicellular organisms and homeotherms, are established when global-scale patterns or large body size ranges are considered (Tilman et al., 2004). However, at the population and within-population scales, where body size ranges are small, deviations from the observed body-size scaling patterns are commonly observed. Specifically, both scaling coefficients (Vignes et al., 2012) and individual metabolic rates deviate from the best approximation of the body-size scaling patterns (Tilman et al., 2004).
Concerning the components of body-size scaling patterns at the intra-species and inter-species levels for the three gammarid species considered in the study, the results presented in this paper show the following:

1. The short-term stochasticity of individual metabolic rates is low.

2. Large body-size independent variation occurs in standard individual metabolic rates within populations, with 
deviation of the observed scaling coefficient from the expected patterns.

3. Standard metabolic rates vary among species that are morphologically closely related, but interspecific variation of average individual metabolic rates is low.

The key results presented in the present paper do not seem to depend on methodological bias. The individual metabolic rates of aquatic organisms are assessed in the literature by various methods including flow through (Vignes et al., 2012), closed system (Toman and Dall, 1998; Remy et al., 2017) and intermittent flow (Svendsen et al., 2016). The latter two methods have been shown to be more sensitive than the former to oxygen stress and accumulation of individual excretion products (Franke, 1977; Gnaiger, 1983; Lampert, 1984). An experiment conducted in a closed chamber with flowing water found that the metabolic rate of Gammarus fossarum directly after transfer was twice as high as it was $4 \mathrm{~h}$ later (Franke, 1977). Moreover, excretory products, which can accumulate in closed and intermittent systems, have been found to be harmful for lotic fauna (Gnaiger, 1983; Lampert, 1984). In the present study, we cleaned the whole apparatus every day and ran checks on blank lines twice a day to monitor eventual background shifts due to bacterial growth, but no background shift was observed. Finally, we did not conduct preliminary experiments to determine the gammarid individuals' optimal time of acclimation to the flow rate in the experimental chamber, assuming that $3 \mathrm{~h}$ was enough. We acknowledge that gammarids were potentially exposed to multiple stresses when in the experimental chamber, due to water flow, limited space and starvation, but the lack of any pairwise difference between repeated assessment times and across the whole period indicates that if stress responses did occur, they must have been very weak. The limited variation across repeated measurements of single individual standard metabolism and the procedure used in the measurement of partial oxygen pressure in the experimental chambers, performed only after a stabilisation of the readings, suggest that consistent measurement errors can be excluded. Therefore, the accuracy and precision of the method we used are strongly supported by the results of the present study. Indeed, the differences between the metabolic rates of individuals from one replicate to another during the experimental period were small, as also seen in Basset and Montalenti (1990) and Wrona and Davies (1984).

Our first conclusion above is supported by the lack of any significant temporal variation in individual metabolic rates during the experiment and by the very low average coefficient of variation of individual metabolic rates among replicated assessments of the same individuals. Flow-through techniques have been used in order to allow experimental measurement of the individual "resting" standard metabolic rate at fixed temperatures (Wrona and Davies, 1984). In our study, the experimental chambers allowed active swimming on the part of the individuals, which is a potential source of variability in individual standard metabolic rates, but generally the chambers were not large enough to exclude stress, which could also affect the standard metabolism of individuals.

Analyses of variation in the standard metabolic rate of single individuals during daylight periods are not common in the literature, since most papers, regardless of the methodology used, perform a single measurement per individual per day. However, our observations are consistent with those of Basset and Montalenti (1990) concerning Gammarus pulex, which also found a low coefficient of variation of metabolic rate among replicates and suggest that the experimental conditions and individual swimming behaviour allowed by the chamber size do not constitute substantial sources of variation in individual standard metabolic rates in the three species of gammarids considered in this study.

Our second conclusion is supported by the fact that body size explained only $12.2 \%$ to $41.7 \%$ of overall interindividual variance in standard metabolic rates in the three studied species. Despite significant differences in both the intercepts of the allometric equations at the population level and the residuals of the pooled allometric regressions, the body weight of each of the three species exerted a strong influence on standard metabolism. Individuals of the two larger species, i.e. G. aequicauda and G. insensibilis, have significantly higher standard metabolic rates than those of the smaller species, i.e. E. olivii, which is supported by the global rule that the metabolic rate is higher in larger animals than smaller ones (Lampert, 1984). Based on the different intercepts of the weight-length relationships and the better body condition in E. olivii than the others, species shape could potentially interfere with metabolic rate.

Typically, the relationship between metabolic (respiration) rate $(R)$ and body mass $(M)$ is expressed as a power function, $R=\alpha M^{b}$. It is widely accepted that the scaling exponent, $b$, is $3 / 4$, the so-called 3/4 power law (Brody, 1945; Hemmingsen, 1960; Kleiber, 1962; McMahon and Bonner, 1983; Peters, 1983; Calder, 1984; Schmidt-Nielsen, 1984; Blaxter, 1989; Brown and West, 2000; Savage et al., 2004). The results of this study confirm the size dependency of the metabolic rates of all the studied species in accordance with the allometric scaling model, with scaling coefficients ranging from 0.32 to 0.36 . These scaling coefficients do not differ from each other, but they are significantly lower than the 0.75 value commonly observed (Kleiber, 1932; Peters, 1983) when interspecific comparisons are performed. Similar results to ours have also been observed in Lekanesphaera monodi along habitat productivity gradients (Vignes et al., 2012). Some of the most convincing evidence against the universality of $3 / 4$ power scaling comes from studies of intraspecific (ontogenetic) metabolic scaling (Glazier, 2005). Indeed, at the intraspecific level the size range is much smaller than in interspecific comparisons, and it has already been shown that under such conditions, factors other than body mass can affect individual metabolic rates (West et 
al., 1997). Based on a review of the literature, Glazier (2005) found that scaling coefficients show departures from the Kleiber-Peters scaling exponent $(b=0.75)$ even for species with a wide range of body sizes (up to 5 orders of magnitude). He also found a wide range of variation of the scaling coefficient, from $b=-1.20$ to $b=2.05$, for invertebrate species (Glazier, 2005). The metabolic rate allometric scaling coefficients observed for the three species in this study are well within this range, although they are lower than the average values that have been observed for amphipods generally.

Our third conclusion is supported by the comparison of residuals, which were calculated for the three species using a single pooled equation, demonstrating that the metabolic rate of $E$. olivii was significantly lower than those of $G$. aequicauda and $G$. insensibilis. The difference among species might be attributable to different osmoregulation and energetic costs along the salinity gradient between freshwater and marine ecosystems. This explanation was also proposed by Sutcliffe (1984). Glazier and Sparks (1997) showed that freshwater and estuarine gammarid species have significantly higher metabolic rates than those of marine species. In general, the mean metabolic rate of freshwater species is $60 \%-$ $65 \%$ higher than that of brackish-marine species (Sutcliffe, 1984). Thienemann (1928) suggested that oxygen uptake is easier in water with higher salinity. Schlieper (1929) measured the metabolic rate of several brackish water animals at various salinities and found that the oxygen consumption of Carcinus generally increased with salinity. Within the gammarids, the brackish water species Gammarus chevreuxi has a higher metabolic rate than the marine Marinogammarus marinus (currently Echinogammarus marinus (Leach, 1815) according to the World Register of Marine Species, WoRMS), while the freshwater Gammarus pulex has a higher metabolic rate than either of them (Potts and Parry, 1964). Therefore, the results found in this paper are in agreement with most of the available evidence on amphipod gammarid species.

The metabolic rate per unit of mass in Echinogammarus olivii, which lives in marine ecosystems, was lower than other species in fresh and brackish waters. This could be related to their osmoregulation energy cost because the haemolymph of marine species is closer to seawater than fresh water, so species living in freshwater ecosystems usually consume more energy for osmoregulation. Similar results were also found by the Graetz (1931) study of the euryhaline stickleback, Gasterosteus, which, despite living for a long period in fresh water, has a higher metabolic rate in fresh water than in isosmotic seawater, where blood chloride equals environmental chloride. Wolvekamp and Waterman (1960) showed that oxygen uptake in freshwater, brackish and marine Gammarus species falls progressively while the salinity of their respective habitats rises.

Water salinity is only one of several abiotic factors that have been observed to affect individual metabolic rates in various species of Crustacea. These include the following: (i) water temperature, including short-term and prolonged fluctuations (Newell, 1969), e.g. various Idotea species (Adcock, 1982; Meyer and Phillipson, 1983; Vetter et al., 1999; Salomon and Buchholz, 2000); (ii) water salinity, with a direct response in terms of standard metabolic rates to increasing water salinity, e.g. Palaemon peringueyi (Allan et al., 2006) and Uca pugnax (Shock et al., 2009), but see also Gammarus oceanicus (Normant et al., 2004); (iii) dissolved oxygen concentration, e.g. Gammarus pseudolimnaeus (Hoback and Barnhart, 1996; a curvilinear "bellshaped" relationship was observed); (iv) habitat productivity, with a direct response of standard metabolic rates to increasing habitat productivity, e.g. Lekanesphaera monodi (Vignes et al., 2012); and (v) resource quality, with a direct response of standard metabolic rates to increasing resource quality, e.g. Gammarus aequicauda fed on live prey or Flabellia petiolata or P. oceanica leaves (Remy et al., 2017).

\section{Conclusion}

The results of this paper show that most variation in the standard metabolic rates of gammarids occurs at the withinpopulation level and is large enough to determine significant deviations from the expected 3/4 metabolic theory law, with much lower scaling coefficients for all species. Standard metabolic rate variation within individuals and between species was lower than within populations, probably since the three selected species were similar in size. The difference standard metabolic rates might also be due to non-adaptive reasons in the three studied species (Garland and Adolph, 1994). However, the lower metabolic cost of E. olivii with respect to both $G$. insensibilis and G. aequicauda might also suggest the need for a greater focus on osmoregulation costs for gammarid species along salinity gradients in order to explain the relevance of marine species as colonisers of transitional water ecosystems (Ciotti et al., 2015).

The results of this study seem to support the arguments of Glazier (2005), i.e. that it is essential to look beyond the $3 / 4$ power law and consider the great diversity of metabolic scaling relationships that exist in the living world and that changes in metabolic rate with individual age can occur due to ontogenetic shifts in individual growth and locomotion costs. Additional studies, disentangling the influence of individual body size and age, are required in order to deepen our understanding of the causes of the observed deviation in the metabolic scaling coefficients of the three gammarid species studied here and more generally the observed deviations in studies at the population level.

Data availability. Data are publicly accessible at OSF with the following link: https://osf.io/nbt65/. 
Author contributions. MC and MS performed the experiment under supervision of $\mathrm{AB}$. MS wrote the first draft of the paper and all the authors contributed, reviewed and approved the final version of the manuscript.

Competing interests. The authors declare that they have no conflict of interest.

Acknowledgements. The authors would like to thank the three anonymous reviewers for providing constructive comments and Sergio Navarrete for the edition.

Edited by: Sergio Navarrete

Reviewed by: three anonymous referees

\section{References}

Adcock, J.: Energetics of a population of Asellus aquaticus (Crustacea, Isopoda): respiration and energy budgets, Freshwater Biol., 12, 257-269, 1982

Akin, S., Buhan, E., and Winemiller, K. O.: Fish assemblage structure of Koycegiz Lagoon-Estuary, Turkey: Spatial and temporal distribution patterns in relation to environmental variation, Estuar. Coast. Shelf S., 64, 671-684, 2005.

Allan, E., Froneman, P., and Hodgson, A.: Effects of temperature and salinity on the standard metabolic rate (SMR) of the caridean shrimp Palaemon peringueyi, J. Exp. Mar. Biol. Ecol., 337, 103108, 2006.

Altermatt, F., Alther, R., Fišer, C., Jokela, J., Konec, M., K üry, D., M ächler, E., Stucki, P., and Westram, A. M.: Diversity and Distribution of Freshwater Amphipod Species in Switzerland (Crustacea: Amphipoda), PLOS ONE, 9, e110328, https://doi.org/10.1371/journal.pone.0110328, 2014.

Barnes, R.: What, if anything, is a brackish-water fauna?, T. Roy. Soc. Edin.-Earth, 80, 235-240, 1989.

Basset, A. and Glazier, D. S.: Resource limitation and intraspecific patterns of weight $\mathrm{x}$ length variation among spring detritivores, Hydrobiologia, 316, 127-137, 1995.

Basset, A. and Montalenti, G.: Tassi respiratori individuali in una popolazione di Gammarus pulex (L.): Ruolo di mole corporea e tassi di ingestione, Rend. Lincei-Sci. Fis., 1, 203-211, 1990.

Basset, A., Elliott, M., West, R. J., and Wilson, J. G.: Estuarine and lagoon biodiversity and their natural goods and services, Estuar. Coast. Shelf S., 132, 1-4, 2013.

Becker, J., Ortmann, C., Wetzel, M. A., and Koop, J. H.: Metabolic activity and behavior of the invasive amphipod Dikerogammarus villosus and two common Central European gammarid species (Gammarus fossarum, Gammarus roeselii): Low metabolic rates may favor the invader, Comp. Biochem. Phys. A, 191, 119-126, 2016.

Blaxter, K.: Energy metabolism in animals and man, CUP Archive, Press Syndicate of the University of Cambridge, New York, 1989.

Boggero, A., Ruocco, M., Shokri, M., Gjoni, V., Ansaloni, I., Zaupa, S., Montagna, M., and Rossaro, B.: Chironomus (Chironomus) Aprilinus Meigen, 1818 (Dipteta Chironomidae), First
Record from Italy: Cytotaxonomy and ecology, Redia, 100, 1117, 2017.

Brody, S.: Bioenergetics and growth: with special reference to the efficiency complex in domestic animals, Bioenergetics and growth: with special reference to the efficiency complex in domestic animals, Reinhold Oxford, England, 1945.

Brown, J. H. and West, G. B.: Scaling in biology, Oxford university press, New York, 2000.

Brown, J. H., Gillooly, J. F., Allen, A. P., Savage, V. M., and West, G. B.: Toward a metabolic theory of ecology, Ecology, 85, 17711789, 2004.

Brucet, S., Boix, D., Nathansen, L. W., Quintana, X. D., Jensen, E., Blayla, D., Meerhoff, M., and Jeppesen, E.: Effects of Temperature, Salinity and Fish in Structuring the Macroinvertebrate Community in Shallow Lakes, Implications for Effects of Climate Change, PLOS ONE, 7, e30877, https://doi.org/10.1371/journal.pone.0030877, 2012.

Bruno, J. F., Carr, L. A., and O'Connor, M. I.: Exploring the role of temperature in the ocean through metabolic scaling, Ecology, 96, 3126-3140, 2015.

Cai, W.-J., Pomeroy, L. R., Moran, M. A., and Wang, Y.: Oxygen and carbon dioxide mass balance for the estuarine-intertidal marsh complex of five rivers in the southeastern U.S., Limnol.Oceanogr., 44, 639-649, 1999.

Calder, W. A.: Size, function, and life history, Courier Corporation, Dover publications, New York, 1984.

Childress, J. J., Cowles, D. L., Favuzzi, J. A., and Mickel, T. J.: Metabolic rates of benthic deep-sea decapod crustaceans decline with increasing depth primarily due to the decline in temperature, Deep-Sea Res., 37, 929-949, 1990.

Ciotti, M., Micaroni, V., Strano, F., Gjoni, V., and Basset, A.: Colonizers or inhabitants, where are transitional water species from? A checklist of Italian lagoons, Transitional Waters Bulletin, 9, 56-99, 2015.

Costanza, R., de Groot, R., Sutton, P., van der Ploeg, S., Anderson, S. J., Kubiszewski, I., Farber, S., and Turner, R. K.: Changes in the global value of ecosystem services, Global Environ. Chang., 26, 152-158, 2014.

Costello, M.: European register of marine species: a check-list of the marine species in Europe and a bibliography of guides to their identification, Paris: Museìum national d'histoire naturelle, 2001.

Cox, R. M., Lovern, M. B., and Calsbeek, R.: Experimentally decoupling reproductive investment from energy storage to test the functional basis of a life-history trade-off, J. Anim. Ecol., 83, 888-898, 2014.

Cozzoli, F., Bouma, T. J., Ysebaert, T., and Herman, P. M. J.: Application of non-linear quantile regression to macrozoobenthic species distribution modelling: Comparing two contrasting basins, Mar. Ecol. Prog. Ser., 475, 119-133, 2013.

Delhey, K. and Kempenaers, B.: Age differences in blue tit Parus caeruleus plumage colour: within-individual changes or colourbiased survival?, J. Avian Biol., 37, 339-348, 2006.

Dorgelo, J.: Comparative ecophysiology of gammarids (Crustacea: Amphipoda) from marine, brackish and fresh-water habitats, exposed to the influence of salinity-temperature combinations. III. Oxygen uptake, Neth. J. Sea Res., 7, 253-266, 1973. 
Duncan, R. P., Forsyth, D. M., and Hone, J.: Testing the metabolic theory of ecology: allometric scaling exponents in mammals, Ecology, 88, 324-333, 2007.

Elliott, M. and Quintino, V.: The Estuarine Quality Paradox, Environmental Homeostasis and the difficulty of detecting anthropogenic stress in naturally stressed areas, Mar. Pollut. Bull., 54, 640-645, 2007.

Fiocca, A., Vadrucci, M., Sammarco, P., and Magazzù, G.: Seasonal cycles of N, P and Si in the Adriatic Coastal Belt of Salento, Ann. Chim., 88, 859-866, 1998.

Forster, J., Hirst, A. G., and Atkinson, D.: Warming-induced reductions in body size are greater in aquatic than terrestrial species, P. Natl. Acad. Sci. USA, 109, 19310-19314, 2012.

Foucreau, N., Cottin, D., Piscart, C., and Hervant, F.: Physiological and metabolic responses to rising temperature in Gammarus pulex (Crustacea) populations living under continental or Mediterranean climates, Comp. Biochem. Phys. A, 168, 69-75, 2014.

Franke, U.: Experimentelle Untersuchungen zur Respiration von Gammarus fossarum Koch 1835 (Crustacea-Amphipoda) in Abhängigkeit von Temperatur, Sauerstoffkonzentration und Wasserbewegung, Arch. Hydrobiol., 48, 369-411, 1977.

Garland, T. and Adolph, S.: Why Not to Do Two-Species Comparative Studies: Limitations on Inferring Adaptation, Physiol. Zool., 67, 797-828, 1994.

Gates, A. R.: The physiological ecology of the specialist lagoon amphipod, Gammarus insensibilis, University of Southampton, Faculty of Engineering Science and Mathematics, School of Ocean and Earth Sciences, doctoral thesis, 216 pp., 2006.

Gilliland, P. M. and Sanderson, W. G.: Re-evaluation of marine benthic species of nature conservation importance: a new perspective on certain "lagoonal specialists" with particular emphasis on Alkmaria romijni Horst (Polychaeta: Ampharetidae), Aquat. Conserv., 10, 1-12, 2000.

Glazier, D. S.: Separating the respiration rates of embryos and brooding females of Daphnia magna: Implications for the cost of brooding and the allometry of metabolic rate, Limnol. Oceanogr., 36, 354-362, 1991.

Glazier, D. S.: Beyond the "3/4-power law": variation in the intraand interspecific scaling of metabolic rate in animals, Biol. Rev., 80, 611-662, 2005.

Glazier, D. S.: Metabolic level and size scaling of rates of respiration and growth in unicellular organisms, Funct. Ecol., 23, 963968, 2009.

Glazier, D. S. and Sparks, B. L.: Forum, Functional Ecology, 11, 126-128, 1997.

Glazier, D. S., Butler, E. M., Lombardi, S. ., Deptola, T. J., Reese, A. J., and Satterthwaite, E. V.: Ecological effects on metabolic scaling: Amphipod responses to fish predators in freshwater springs, Ecol. Monogr., 81, 599-618, 2011.

Glazier, D. S., Hirst, A. G., and Atkinson, D.: Shape shifting predicts ontogenetic changes in metabolic scaling in diverse aquatic invertebrates, P. Roy. Soc. B-Biol. Sci., 282, 20142302, https://doi.org/10.1098/rspb.2014.2302, 2015.

Gnaiger, E.: The twin-flow microrespirometer and simultaneous calorimetry, in: Polarographic Oxygen Sensors: Aquatic and Physiological Applications, edited by: Gnaiger, E. and Forstner, H., Springer Science \& Business Media, Berlin, Heidelberg, $337-345,1983$.
Gönlügür-Demirci, G.: Crustacea fauna of the Turkish Black Sea coasts: a check list, Crustaceana, 79, 1129-1139, 2006.

Graetz, E.: Versuch einer exakten Analyse der zur Osmoregulation benötigten Kräfte in ihrer Beziehung zum Gesamtstoffwechsel von Süßwasserstichlingen in hypo- und hypertonischen Medien, Zool. Jahrb. Allg. Zool., 49, 37-58, 1931.

Gutiérrez, D. and Menéndez, R.: Patterns in the distribution, abundance and body size of carabid beetles (Coleoptera: Caraboidea) in relation to dispersal ability, J. Biogeogr., 24, 903-914, 1997.

Halcrow, K. and Boyd, C. M.: The oxygen consumption and swimming activity of the amphipod Gammarus oceanicus at different temperatures, Comp. Biochem. Physiol., 23, 233-242, 1967.

Hamburger, K. and Dall, P. C.: The respiration of common benthic invertebrate species from the shallow littoral zone of Lake Esrom, Denmark, Hydrobiologia, 199, 117-130, 1990.

Hart, R. C. and Bychek, E. A.: Body size in freshwater planktonic crustaceans: an overview of extrinsic determinants and modifying influences of biotic interactions, Hydrobiologia, 668, 61108, 2011.

Hemmingsen, A. M.: Energy metabolism as related to body size and respiratory surfaces, and its evolution, Reports of the Steno Memorial Hospital and Nordisk Insulin Laboratorium, 9, 1-110, 1960.

Herrera, C. M.: The ecology of subindividual variability in plants: patterns, processes, and prospects, Web Ecol., 17, 51-64, 2017.

Hirst, A. G., Glazier, D. S., and Atkinson, D.: Body shape-shifting during growth permits tests that distinguish between competing geometric theories of metabolic scaling, Ecol. Lett., 17, 12741281, 2014.

Hoback, W. W. and Barnhart, M. C.: Lethal limits and sublethal effects of hypoxia on the amphipod Gammarus pseudolimnaeus, J. N. Am. Benthol. Soc., 15, 117-126, 1996.

Hull, V., Parrella, L., and Falcucci, M.: Modelling dissolved oxygen dynamics in coastal lagoons, Ecol. Model., 211, 468-480, 2008.

Ivleva, I. V. : The Dependence of Crustacean Respiration Rate on Body Mass and Habitat Temperature, Int. Revue ges. Hydrobiol. Hydrogr., 65, 1-47, 1980.

Jakob, E. M., Marshall, S. D., and Uetz, G. W.: Estimating fitness: A comparison of body condition indices,. Oikos, 77, 61-67, 1996.

Johnston, E. L., Mayer-Pinto, M., Crowe, T. P., and Frid, C.: REVIEW: Chemical contaminant effects on marine ecosystem functioning, J. Appl. Ecol., 52, 140-149, 2015.

Kevrekidis, T. and Koukouras, A.: Life cycle and reproduction of Gammarus aequicauda (Crustacea: Amphipoda) in the Evros Delta (NE Greece), Israel J. Zool., 35, 137-149, 1988.

Killen, S. S., Atkinson, D., and duncan, D. S.: The intraspecific scaling of metabolic rate with body mass in fishes depends on lifestyle and temperature, Ecol. Lett., 13, 184-193, 2010.

Kleiber, M.: Body size and metabolism, Hilgardia, 6, 315-353, 1932.

Kleiber, M.: The fire of life: an introduction to animal energetics, J. Pharm. Sci.-US, 5, 497 pp., 1962.

Lagos, M. E., White, C. R., and Marshall, D. J.: Do invasive species live faster? Mass-specific metabolic rate depends on growth form and invasion status, Funct. Ecol., 31, 2080-2086, 2017.

Lampert, W.: The Measurement of Respiration, in: A Manual on Methods for the Assessment of Secondary Productivity in Fresh Waters, 2nd edn., edited by: Downing, J. A. and Rigler, F. H., Blackwell Scientific, Oxford, 1984. 
Lannig, G., Eilers, S., Pörtner, H. O., Sokolova, I. M., and Bock, C.: Impact of Ocean Acidification on Energy Metabolism of Oyster, Crassostrea gigas-Changes in Metabolic Pathways and Thermal Response, Mar. Drugs., 8, 2318-2339, 2010.

Löwenstein, O.: The Respiratory Rate of Gammarus chevreuxi in Relation to Differences in Salinity, J. Exp. Biol., 12, 217-221, 1935.

Maci, S. and Basset, A.: Spatio-temporal patterns of abundance, size structure and body condition of Atherina boyeri (Pisces: Atherinidae) in a small non-tidal Mediterranean lagoon, Estuar. Coast. Shelf S., 87, 125-134, 2010.

Madricardo, F., Foglini, F., Kruss, A., Ferrarin, C., Pizzeghello, N. M., Murri, C., Rossi, M., Bajo, M., Bellafiore, D., Campiani, E., Fogarin, S., Grande, V., Janowski, L., Keppel, E., Leidi, E., Lorenzetti, G., Maicu, F., Maselli, V., Mercorella, A., Montereale Gavazzi, G., Minuzzo, T., Pellegrini, C., Petrizzo, A., Prampolini, M., Remia, A., Rizzetto, F., Rovere, M., Sarretta, A., Sigovini, M., Sinapi, L., Umgiesser, G., and Trincardi, F.: High resolution multibeam and hydrodynamic datasets of tidal channels and inlets of the Venice Lagoon, scientific data, 4, 170121, https://doi.org/10.1038/sdata.2017.121, 2017.

McMahon, T. A. and Bonner, J. T.: On size and life, Scientific American Library, New York, 1983.

Meyer, E. and Phillipson, J.: Respiratory metabolism of the isopod Trichoniscus pusillus provisorius, Oikos, 40, 69-74, 1983.

Naylor, C., Maltby, L., and Calow, P.: Scope for growth in Gammarus pulex, a freshwater benthic detritivore, Hydrobiologia, 188, 517-523, 1989.

Newell, R. C.: Effect of fluctuations in temperature on the metabolism of intertidal invertebrates, Am. Zool., 9, 293-307, 1969.

Normant, M., Schmolz, E., and Lamprecht, I.: Heat production rate of the Baltic amphipod Gammarus oceanicus at varying salinities, Thermochim. Acta, 415, 135-139, 2004.

Peig, J. and Green, A. J.: New perspectives for estimating body condition from mass/length data: the scaled mass index as an alternative method, Oikos, 118, 1883-1891, 2009.

Pérez-Ruzafa, A., Fernández, A. I., Marcos, C., Gilabert, J., Quispe, J. I., and García-Charton, J. A.: Spatial and temporal variations of hydrological conditions, nutrients and chlorophyll $a$ in a Mediterranean coastal lagoon (Mar Menor, Spain), Hydrobiologia, 550, 11-27, 2005.

Peters, R. H.: The ecological implications of body size, Cambridge University Press, New York, 1983.

Petersen, R. C. and Cummins, K. W.: Leaf processing in a woodland stream, Freshwater Biol., 4, 343-368, 1974.

Piersma, T. and Lindström, ̊.: Rapid reversible changes in organ size as a component of adaptive behaviour, Trends Ecol. Evol., 12, 134-138, 1997.

Pinkster, S.: A Revision of the genus Echinogammarus Stebbing, 1899 with some notes on related genera (Crustacea, Amphipoda), Memorie del Museo Civico di Storia Naturale di Verona (Series 2), 10, 185 pp., 1993.

Potts, W. T. W. and Parry, G.: Osmotic and ionic regulation in animals, Pergamon press, New York, 438 pp, 1964.

Prato, E. and Biandolino, F.: Amphipod biodiversity of shallow water in the Taranto seas (north-western Ionian Sea), J. Mar. Biol. Assoc. UK, 85, 333-338, 2005.
Remy, F., Darchambeau, F., Melchior, A., and Lepoint, G.: Impact of food type on respiration, fractionation and turnover of carbon and nitrogen stable isotopes in the marine amphipod Gammarus aequicauda (Martynov, 1931), J. Exp. Mar. Biol. Ecol., 486, 358-367, 2017.

Rowe, L. and Houle, D.: The Lek Paradox and the Capture of Genetic Variance by Condition Dependent Traits, P. Roy. Soc. London B, 263, 1415-1421, 1996.

Ruffo, S.: The Amphipoda of the Mediterranean, Memoires de l'Institut Océanographique, Monaco, 1982.

Salomon, M. and Buchholz, F.: Effects of temperature on the respiration rates and the kinetics of citrate synthase in two species of Idotea (Isopoda, Crustacea), Comp. Biochem. Phys. B, 125, 71-81, 2000.

Savage, V. M., Gillooly, J., Woodruff, W., West, G., Allen, A., Enquist, B. J., and Brown, J.: The predominance of quarter-power scaling in biology, Funct. Ecol., 18, 257-282, 2004.

Schlieper, C.: Über die Einwirkung niederer Salzkonzentrationen auf marine Organismen, J. Comp. Physiol. A, 9, 478-514, 1929.

Schmidt-Nielsen, K.: Scaling: why is animal size so important?, Cambridge University Press, New York, 1984.

Schulte-Hostedde, A. I., Zinner, B., Millar, J. S., and Hickling, G. J.: Restitution of mass-size residuals: validating body condition, Ecology, 86, 155-163, 2005.

Shock, B. C., Foran, C. M., and Stueckle, T. A.: Effects of Salinity Stress on Survival, Metabolism, Limb Regeneration, and Ecdysis in Uca Pugnax, J. Crustacean Biol., 29, 293-301, 2009.

Shokri, M., Rossaro, B., and Rahmani, H.: Response of macroinvertebrate communities to anthropogenic pressures in Tajan River (Iran), Biologia, 69, 1395-1409, 2014.

Sides, C. B., Enquist, B. J., Ebersole, J. J., Smith, M. N., Henderson, A. N., and Sloat, L. L.: Revisiting Darwin's hypothesis: Does greater intraspecific variability increase species' ecological breadth?, Am. J. Bot., 101, 56-62, 2014.

Siefert, A., Violle, C., Chalmandrier, L., Albert, C. H., Taudiere, A., Fajardo, A., Aarssen, L. W., Baraloto, C., Carlucci, M. B., Cianciaruso, M. V., Dantas, V. D., de Bello, F., Duarte, L. D. S., Fonseca, C. R., Freschet, G. T., Gaucherand, S., Gross, N., Hikosaka, K., Jackson, B., Jung, V., Kamiyama, C., Katabuchi, M., Kembel, S. W., Kichenin, E., Kraft, N. J. B., Lagerstrom, A., Le Bagousse-Pinguet, Y., Li, Y. Z., Mason, N., Messier, J., Nakashizuka, T., Overton, J. McC., Peltzer, D. A., Perez-Ramos, I. M., Pillar, V. D., Prentice, H. C., Richardson, S., Sasaki, T., Schamp, B. S., Schöb, C., Shipley, B., Sundqvist, M., Sykes, M. T., Vandewalle, M., and Wardle, D. A.: A global meta-analysis of the relative extent of intraspecific trait variation in plant communities, Ecol. Lett., 18, 1406-1419, 2015.

Sieg, A. E., O'Connor, M. P., McNair, J. N., Grant, B. W., Agosta, S. J., and Dunham, A. E.: Mammalian metabolic allometry: do intraspecific variation, phylogeny, and regression models matter?, Am. Nat., 174, 720-733, 2009.

Speakman, J. R., Król, E., and Johnson, M. S.: The Functional Significance of Individual Variation in Basal Metabolic Rate, Physiol. Biochem. Zool., 77, 900-915, 2004.

Stamps, J. A., Briffa, M., and Biro, P. A.: Unpredictable animals: individual differences in intraindividual variability (IIV), Anim. Behav., 83, 1325-1334, 2012. 
Sutcliffe, D. W.: Quantitative aspects of oxygen uptake by Gammarus (Crustacea, Amphipoda): a critical review, Freshwater Biol., 14, 443-489, 1984.

Svendsen, M. B., Bushnell, P. G., and Steffensen, J. F.: Design and setup of intermittent-flow respirometry system for aquatic organisms, J. Fish Biol., 88, 26-50, 2016.

Taylor, H. H. and Leelapiyanart, N.: Oxygen uptake by embryos and ovigerous females of two intertidal crabs, Heterozius rotundifrons (Belliidae) and Cyclograpsus lavauxi (Grapsidae): scaling and the metabolic costs of reproduction, J. Exp. Biol., 204, 1083-1097, 2001.

Tedengren, M., Arner, M., and Kautsky, N.: Ecophysiology and stress response of marine and brackish water Gammarus species (Crustacea, Amphipoda) to changes in salinity and exposure to cadmium and diesel-oil, Mar. Ecol. Prog. Ser., 47, 107-116, 1988.

Thienemann, A.: Mysis relicta in sauerstoffarmem Tiefenwasser der Ostsee und das Problem der Atmung im Salzwasser und Süßwasser, Zool. Jahrbuch, 45, 371-384, 1928.

Tilman, D., HilleRisLambers, J., Harpole, S., Dybzinski, R., Fargione, J., Clark, C., and Lehman, C.: Does metabolic theory apply to community ecology? its a matter of scale, Ecology, 85, 1797-1799, 2004.

Toman, M. J. and Dall, P. C.: Respiratory levels and adaptations in four freshwater species of Gammarus (Crustacea: Amphipoda), Int. Rev. Hydrobiol., 83, 251-263, 1998.

Varigin, A. Y.: Sexual structure of population and reproduction cycle of Echinogammarus olivii (Crustacea, Isopoda) in the fouling community of Odessa Bay (Black Sea), Biosystems Diversity, 23, 39-43, 2015.

Verschut, T. A., Meineri, E., and Basset, A.: Biotic interactions affect the colonization behavior of aquatic detritivorous macroinvertebrates in a heterogeneous environment, Estuar. Coast. Shelf S., 157, 120-128, 2015.
Vetter, R.-A. H., Franke, H.-D., and Buchholz, F.: Habitat-related differences in the responses to oxygen deficiencies in Idotea baltica and Idotea emarginata (Isopoda, Crustacea), J. Exp. Mar. Biol. Ecol., 239, 259-272, 1999.

Vignes, F., Fedele, M., Pinna, M., Mancinelli, G., and Basset, A.: Variability of Lekanesphaera monodi metabolic rates with habitat trophic status, Acta Oecol., 41, 58-64, 2012.

West, G. B., Brown, J. H., and Enquist, B. J.: A general model for the origin of allometric scaling laws in biology, Science, 276, 122-126, 1997.

West, G. B., Woodruff, W. H., and Brown, J. H.: Allometric scaling of metabolic rate from molecules and mitochondria to cells and mammals, P. Natl. Acad. Sci. USA, 99, 2473-2478, 2002.

White, C. R., Cassey, P., and Blackburn, T. M.: Allometric exponents do not support a universal metabolic allometry, Ecology, 88, 315-323, 2004.

White, C. R., Blackburn, T. M., and Seymour, R. S.: Phylogenetically informed analysis of the allometry of mammalian basal metabolic rate supports neither geometric nor quarter-power scaling, Evolution, 63, 2658-2667, 2009.

Wilhelm, F. M., Taylor, S. J., and Adams, G. L.: Comparison of routine metabolic rates of the stygobite, Gammarus acherondytes (Amphipoda: Gammaridae) and the stygophile, Gammarus troglophilus, Freshwater Biol., 51, 1162-1174, 2006.

Wolvekamp, H. P. and Waterman, T. H.: Respiration, in: The Physiology of Crustacea, edited by: Waterman, T. H., Academic Press Inc., New York, London, 35-100, 1960.

Wrona, F. J. and Davies, R. W.: An improved flow-through respirometer for aquatic macroinvertebrate bioenergetic research, Can. J. Fish. Aquat. Sci., 41, 380-385, 1984.

Xiao, B., Li, E., Du, Z., Jiang, R., Chen, L., and Yu, N.: Effects of temperature and salinity on metabolic rate of the Asiatic clam Corbicula fluminea (Müller, 1774), SpringerPlus, 3, 455, https://doi.org/10.1186/2193-1801-3-455, 2014. 